\title{
Effects of dietary plant meal and soya-saponin supplementation on intestinal and hepatic lipid droplet accumulation and lipoprotein and sterol metabolism in Atlantic salmon (Salmo salar L.)
}

\author{
Min $\mathrm{Gu}^{1,2_{*}}$, Trond M. Kortner ${ }^{1}$, Michael Penn ${ }^{1}$, Anne Kristine Hansen ${ }^{3}$ and Åshild Krogdahl ${ }^{1}$ \\ ${ }^{1}$ Department of Basic Science and Aquatic Medicine, Norwegian School of Veterinary Science, \\ Aquaculture Protein Centre (a CoE), PO Box 8146 Dep, NO-0033 Oslo, Norway \\ ${ }^{2}$ The Key Laboratory of Mariculture (Ministry of Education), Ocean University of China, \\ 5 Yushan Road, Qingdao, Shandong 266003, People's Republic of China \\ ${ }^{3}$ Nofima AS, NO-6600 Sunndalsøra, Norway
}

(Submitted 14 February 2013 - Final revision received 17 June 2013 - Accepted 18 July 2013 - First published online 5 September 2013)

\begin{abstract}
Altered lipid metabolism has been shown in fish fed plant protein sources. The present study aimed to gain further insights into how intestinal and hepatic lipid absorption and metabolism are modulated by plant meal (PM) and soya-saponin (SA) inclusion in salmon feed. Post-smolt Atlantic salmon were fed for 10 weeks one of four diets based on fishmeal or PM, with or without $10 \mathrm{~g} / \mathrm{kg}$ SA. PM inclusion resulted in decreased growth performance, excessive lipid droplet accumulation in the pyloric caeca and liver, and reduced plasma cholesterol levels. Intestinal and hepatic gene expression profiling revealed an up-regulation of the expression of genes involved in lipid absorption and lipoprotein (LP) synthesis (apo, fatty acid transporters, microsomal TAG transfer protein, acyl-CoA cholesterol acyltransferase, choline kinase and choline-phosphate cytidylyltransferase A), cholesterol synthesis (3-hydroxy-3-methylglutaryl-CoA reductase) and associated transcription factors (sterol regulatory element-binding protein 2 and PPAR $\gamma$ ). SA inclusion resulted in reduced body pools of cholesterol and bile salts. The hepatic gene expression of the rate-limiting enzyme in bile acid biosynthesis (cytochrome $\mathrm{P} 4507 \mathrm{~A} 1$ (cyp7a1)) as well as the transcription factor liver $\mathrm{X}$ receptor and the bile acid transporter abcb11 (ATP-binding cassette B11) was down-regulated by SA inclusion. A significant interaction was observed between PM inclusion and SA inclusion for plasma cholesterol levels. In conclusion, gene expression profiling suggested that the capacity for LP assembly and cholesterol synthesis was up-regulated by PM exposure, probably as a compensatory mechanism for excessive lipid droplet accumulation and reduced plasma cholesterol levels. SA inclusion had hypocholesterolaemic effects on Atlantic salmon, accompanied by decreased bile salt metabolism.
\end{abstract}

Key words: Lipoproteins: Sterols: Plant meal: Soya-saponins: Quantitative real-time PCR

For the majority of intensively reared carnivorous finfish species, such as salmonids, fishmeal (FM) is traditionally used as the protein source. While global aquaculture production has continued to grow, FM usage has remained static ${ }^{(1)}$. The limited supply of FM has led to increased interest in using plant proteins as alternatives to marine fishery-derived proteins. Nevertheless, inclusion of plant protein sources in aquafeeds is limited since a number of disadvantages have been recognised. Besides the negative effect on growth performance and intestinal function ${ }^{(2-5)}$, plant protein inclusion in fish feeds has been reported to be associated with decreased lipid digestibility, reduced bile salt levels and hypocholesterolaemia, suggesting an altered regulation of lipid metabolic pathways ${ }^{(6-13)}$.
The increased economical and quantitative importance of dietary plant protein sources in commercial fish feeds demands a better understanding of lipid metabolic processes such as absorption, transport and synthesis to improve feed utilisation and production cost optimisation.

The major lipid constituents of both natural and commercial salmonid diets are generally TAG with smaller amounts of phospholipids and cholesterol esters ${ }^{(14)}$. In monogastrics, TAG are hydrolysed in the intestinal lumen into NEFA (FA) and monoacylglycerols. Intracellularly, these hydrolysis products are carried by specific binding proteins to the endoplasmic reticulum, where they are resynthesised into TAG and incorporated into lipoproteins (LP). The formation of LP is

\footnotetext{
Abbreviations: $a b c g 5$, ATP-binding cassette G5; $c d 36$, cluster of differentiation 36; fabp2, fatty acid-binding protein 2; fatp, fatty acid transport protein; FA, fatty acids; FM, fishmeal; lxr, liver X receptor; LP, lipoproteins; MTP, microsomal TAG transfer protein; PC, phosphatidylcholine; PM, plant meal; $\operatorname{srebp} 2$, sterol regulatory element-binding protein 2; SA, soya-saponin.
}

*Corresponding author: M. Gu, fax +86 532 82032145, email gumin.ouc@gmail.com 
mediated by the microsomal TAG transfer protein (MTP), which shuttles resynthesised TAG onto a newly formed apoB molecule. This primordial LP particle undergoes further lipidation with the addition of TAG and cholesterol esters by MTP, and phospholipids, apoAIV and, at a later stage, apoAI are added to the surface of the LP particle. This LP particle is then secreted by exocytosis via the basolateral membrane into the lymph ${ }^{(15,16)}$. It has been suggested that the mechanism of lipid absorption and LP formation in fish intestine does not differ fundamentally from that in monogastric mammals ${ }^{(17,18)}$. However, information is still lacking regarding the routes of lipid transport from the intestine. A lymphatic system has not been identified in fish yet.

Saponins are heat-stable glycosides present in legumes, such as soyabean, pea and lupin ${ }^{(19,20)}$. Saponins, with their membrane-permeabilising activity $^{(21)}$, are considered to be the factors responsible for the development of the distal intestine enteritis induced by soyabean meal in Atlantic salmon $^{(22,23)}$. Based on their detergent and surfactant properties $^{(21)}$, dietary saponins probably disturb fat emulsification and micelle formation, but information necessary to understand their significance in lipid metabolism in fish is scarce. In general, saponins exhibit hypocholesterolaemic effects in a variety of animals ${ }^{(24-28)}$, but these effects may be dependent on interactions with other plant components ${ }^{(29-31)}$. It has also been noted that a saponin-induced reduction of serum cholesterol levels occurs only when an otherwise hypocholesterolaemic diet has been $\mathrm{fed}^{(32)}$. It appears as if interactions between saponins and other components in plant meal are necessary for the effects on lipid metabolism, but information on these interactions is scarce.

The present study is a part of a larger experiment investigating the dose response of soya-saponin (SA) inclusion in plant meal- and FM-based diets at levels of 0, 2, 4, 6 and $10 \mathrm{~g} / \mathrm{kg}$. This part of the study aimed to understand how lipid absorption and metabolism are modulated by variation in protein source, saponin inclusion $(10 \mathrm{~g} / \mathrm{kg})$, and the possible interaction between them in salmon feed. Intestinal and hepatic transcript levels of specific apo (apoAI, apoAIV and $a p o B$ ), key enzymes ( $m t p$, acyl-CoA cholesterol acyltransferase (acat), monoacylglycerol acyltransferase (mgat), choline kinase $(c h k)$ and choline-phosphate cytidylyltransferase $\mathrm{A}(p c y t 1 a))$ and FA transporters (cluster of differentiation 36 (cd36), fatty acid transport protein (fatp) and fatty acidbinding protein $2(f a b p 2)$ ) were quantified using quantitative real-time PCR. We also quantified the hepatic expression of key genes involved in cholesterol and bile salt metabolism as described previously ${ }^{(33)}$. Total bile salt levels in the plasma and intestinal contents as well as plasma cholesterol levels were measured. Histomorphological alterations in the pyloric caeca and liver after dietary treatments were evaluated. Our hypothesis was that plant meal and SA inclusion in salmon feed would cause alterations in the expression levels of genes involved in lipid and sterol metabolism and that the differential expression would be reflected in alterations in blood plasma sterol levels and tissue lipid accumulation.

\section{Materials and methods}

\section{Feed ingredients and diet formulation}

SA (95\% concentrate) was obtained from Organic Technologies. FM, lupin meal and wheat gluten meal were used as primary protein sources. Fish oil and wheat meal were used as lipid and carbohydrate sources, respectively. For the present experiment, two basal diets were formulated: a FM-based diet (FM diet) with $587 \mathrm{~g} / \mathrm{kg} \mathrm{FM}$ and a plant mealbased diet (PM diet) with $60 \%$ substitution of FM $(235 \mathrm{~g} / \mathrm{kg}$ FM, $200 \mathrm{~g} / \mathrm{kg}$ lupin meal and $190 \mathrm{~g} / \mathrm{kg}$ wheat gluten meal). The diets were formulated to be isoenergetic ( $24 \mathrm{MJ} / \mathrm{kg}$ gross energy). The fish investigated in the present study were fed one of the basal diets or diets produced from the basal diets supplemented with $10 \mathrm{~g} \mathrm{SA} / \mathrm{kg}$. This saponin level is supposed to correspond to the level present in a diet in which a saponinrich soyabean meal provides all the dietary protein. All diets were supplemented with standard vitamins and minerals to meet the requirements ${ }^{(34)}$. The diets were produced by Nofima AS, with a pellet size of $5 \mathrm{~mm}$. Detailed diet formulations are given in Table 1.

\section{Experimental animals and design}

The feeding trial was carried out at the Nofima Marine research station at Sunndalsøra (Norway) and in compliance with laws regulating experimentation with live animals in Norway, as overseen by the Norwegian Animal Research Authority (Forsøksdyrutvalget). The experiment was carried out using a $2 \times 2$ factorial design with four dietary treatments. Furthermore, two factors, PM inclusion and SA inclusion, were

Table 1. Formulation of the experimental diets

\begin{tabular}{|c|c|c|c|c|}
\hline Ingredients $(\mathrm{g} / \mathrm{kg})$ & FM & FM-SA & PM & PM-SA \\
\hline $\mathrm{FM}^{*}$ & 587 & 587 & 235 & 235 \\
\hline Lupin meal† & & & 200 & 200 \\
\hline Wheat gluten $\ddagger$ & & & 190 & 190 \\
\hline Wheat meal & 156 & 156 & 67 & 67 \\
\hline Soya-saponin§ & & 10 & & 10 \\
\hline Wheat starch & 10 & & 10 & \\
\hline Fish oilll & 221 & 221 & 242 & 242 \\
\hline Vitamin mix & 20 & 20 & 20 & 20 \\
\hline Mineral mixף & 5 & 5 & 5 & 5 \\
\hline $\mathrm{Ca}\left(\mathrm{H}_{2} \mathrm{PO}_{4}\right) \cdot 2 \mathrm{H}_{2} \mathrm{O}$ & & & 10 & 10 \\
\hline Carophyll pink & 0.4 & 0.4 & 0.4 & 0.4 \\
\hline Yttrium oxide ${ }^{\star \star}$ & 0.1 & 0.1 & 0.1 & 0.1 \\
\hline Lys $\mathrm{HCl}$ & & & 17 & 17 \\
\hline DL-Met & & & 3.6 & 3.6 \\
\hline \multicolumn{5}{|l|}{ Chemical composition (\%) } \\
\hline Crude protein & $42 \cdot 3$ & $42 \cdot 3$ & $44 \cdot 1$ & $44 \cdot 1$ \\
\hline Crude lipid & $29 \cdot 3$ & 29.3 & $30 \cdot 3$ & $30 \cdot 3$ \\
\hline Starch & $10 \cdot 3$ & $10 \cdot 3$ & 7.5 & 7.5 \\
\hline Energy (MJ gross energy/kg) & 23.9 & 23.9 & $24 \cdot 2$ & $24 \cdot 2$ \\
\hline
\end{tabular}

FM, fish meal; FM-SA, fish meal with soya-saponin; PM, plant meal; PM-SA, plant meal with soya-saponin.

* Fishmeal 122/11, LTQ fishmeal, produced by Welcon AS.

† Supplied by Holtermann AS.

$\ddagger$ Wheat gluten 159/10, Amytex 100, produced by Syral.

$\S 95 \%$ Concentrate, supplied by Organic Technologies.

|l Fishoil 05/10, NorSalmOil, produced by Norsildmel.

I Supplemented to meet the requirements.

** Marker for the evaluation of nutrient digestibility. 
Table 2. Primer pair sequences, efficiency, amplicon size and annealing temperature for the genes ${ }^{\star}$ used for real-time PCR

\begin{tabular}{|c|c|c|c|c|c|c|}
\hline \multirow[b]{2}{*}{ Gene symbols } & \multicolumn{2}{|c|}{$5^{\prime}-3^{\prime}$ primer sequence } & \multirow{2}{*}{$\begin{array}{l}\text { Amplicon } \\
\text { size (bp) }\end{array}$} & \multirow{2}{*}{$\begin{array}{c}\text { Annealing } \\
\text { temperature }\left({ }^{\circ} \mathrm{C}\right)\end{array}$} & \multirow{2}{*}{$\begin{array}{l}\text { Primer } \\
\text { efficiency }\end{array}$} & \multirow{2}{*}{$\begin{array}{l}\text { GenBank } \\
\text { accession no. }\end{array}$} \\
\hline & Forward & Reverse & & & & \\
\hline mgat2a & acgctacaggcttcaggaaa & ggaatcagacctgccatcat & 116 & 60 & 2.05 & NM_001140718 \\
\hline$a p o B_{\text {liver }} t$ & ttgcagagacctttaagttcattca & tgtgcagtggttgccttgac & 120 & 60 & 1.94 & X81856 \\
\hline$a p o B_{\text {intestine }} \neq$ & ccctgagatggtgtccgtat & gcgtcgacttccatagcttc & 131 & 63 & 1.80 & CB504205 \\
\hline apoAl & ctggtcctcgcactaaccat & tggacctctgtgcagtcaac & 144 & 60 & 1.96 & NM_001123663 \\
\hline apoAIV & caggaccagtctcagcaaca & gttgacttcctgtgccacct & 131 & 60 & 1.90 & ВТ0̈8822 \\
\hline$m t p$ & aacgtgacagtggacatgga & ggaccgtggtgatgaagtct & 89 & 60 & $2 \cdot 00$ & CA042356 \\
\hline acat & tgctggagtttgacctgttg & gctgcgatggtagagagtcc & 139 & 60 & 1.98 & GE793368 \\
\hline chk & ctcaagtttgcccgtctgat & cacaggggaatgagtggagt & 88 & 60 & 1.94 & DY706802 \\
\hline pcyt1a & cgggtctatgcagatggaat & gctcgtcctcgttcatcact & 166 & 60 & 2.09 & ВT045986 \\
\hline$c d 36$ & caagtcagcgacaaaccaga & aggagacatggcgatgtagg & 91 & 60 & 1.93 & AY606034 \\
\hline fatp & aggagagaacgtctccacca & cgcatcacagtcaaatgtcc & 159 & 60 & 1.88 & CA373015 \\
\hline fabp2a1§ & ggtgctgaaaactaccagagcca & ggatttgaacgtagctcttcttgg & 152 & 60 & 2.00 & EU880417 \\
\hline fabp $2 b \S$ & tgccttcccctcattctcta & ggtgatacggtcttcatccaa & 82 & 60 & 2.00 & EU880419 \\
\hline ppar $\propto \S$ & gcttcatcaccagggagttt & tcactgtcatccagctccag & 113 & 60 & 1.99 & NM_0011235960 \\
\hline ppar $\S \S$ & tgctgcaggctgagtttatg & caggggaaagtgtctgtggt & 107 & 58 & 1.96 & NM_0011235946 \\
\hline hmgcrll & ccttcagccatgaactggat & tcctgtccacaggcaatgta & 224 & 60 & 1.88 & NM_001173919 \\
\hline srebp2\| & tcgcggcctcctgatgatt & agggctaggtgactgttctgg & 147 & 60 & 1.91 & HM̄̄561861 \\
\hline сур7а19 & tcctcaacaccctggagaac & cagcatggtcttagccaggt & 125 & 63 & 2.03 & BT059202 \\
\hline$a b c g 59$ & agactgcctcgtccaacact & ccattttcgtgaacgtgtacc & 157 & 60 & 1.94 & CU073172 \\
\hline$a b c b 11^{* *}$ & ccgaccagggcaaagtgatt & cagaatgggctcctgggatac & 101 & 60 & 1.92 & NM_001124656 \\
\hline$f x r^{\oplus}$ & ttcaacatctcaactcatca & tagcaggtcctcattgat & 102 & 60 & $2 \cdot 01$ & NM_001173830 \\
\hline $\mid x r \|$ & gccgccgctatctgaaatctg & caatccggcaaccaatctgtagg & 210 & 60 & 1.88 & FJ47̄0290 \\
\hline
\end{tabular}

mgat2a, monoacylglycerol acyltransferase 2-A; mtp, microsomal TAG transfer protein; acat, acyl-CoA cholesterol acyltransferase; chk, choline kinase; pcyt1a, choline-phosphate cytidylyltransferase 1A; cd36, cluster of differentiation 36; fatp, fatty acid transport protein; fabp2a1/fabp2b, fatty acid-binding protein 2 isoforms; ppar $\alpha / p p a r \gamma$, PPAR isoforms; hmgcr, 3-hydroxy-3-methylglutaryl-CoA reductase; srebp2, sterol regulatory element-binding protein 2; cyp7a1, cytochrome P450 7A1; abcg5, ATP-binding cassette $\mathrm{G} 5$; $a b c b 11$, ATP-binding cassette B11; fxr, farnesoid X receptor; Ixr, liver X receptor.

${ }^{*}$ Readers can refer to a previous study ${ }^{(35)}$ for reference gene primer details.

†Primers obtained from Torstensen et al. ${ }^{(77)}$. High expression was found in the liver and very low expression in the pyloric caeca.

† Primers designed in $5^{\prime}$ end of apoB transcript. High expression was found in the pyloric caeca.

$\S$ Primers obtained from Venold et al. ${ }^{(78)}$.

$\|$ Primers obtained from Minghetti et al. ${ }^{(79)}$.

T Primers obtained from Kortner et al. ${ }^{(33)}$

** Primers obtained from Zaja et al. ${ }^{(80)}$.

tested separately and in combination. Post-smolt Atlantic salmon (Salmo salar L.) of the Sunndalsøra strain with an initial weight of $442(\operatorname{sem} 4) \mathrm{g}$ were allocated to eight $1 \mathrm{~m}^{3}$ fibreglass tanks, twenty-two fish per tank, with 250 litres of seawater flowing at a rate of 20 litres $/ \mathrm{min}$. Fish present in duplicate tanks were fed one of the four experimental diets. During the feeding trial, water temperature was decreased from 12 to $9^{\circ} \mathrm{C}$. The oxygen content and salinity of the outlet water were monitored. Salinity ranged between 32 and $33 \mathrm{~g} / \mathrm{l}$. Fish were continuously fed by automatic disc feeders. A $24 \mathrm{~h}$ lighting regimen was employed during the experimental period.

\section{Sampling}

Sampling was conducted following 10 weeks of feeding the experimental diets. Randomly selected fish were anaesthetised with tricaine methanesulphonate (MS222; Argent Chemical Laboratories) and subsequently killed by a sharp blow to the head. Only the fish that had digesta throughout the intestinal tract were sampled to ensure intestinal exposure to the diets. The intestines were cleared of all fatty tissue and intestinal content before the collection of tissue samples. Pyloric caecal and liver tissues were sampled from four fish from each tank for mRNA extraction, placed in RNAlater (Ambion) at $4^{\circ} \mathrm{C}$ for $24 \mathrm{~h}$ and then stored at $-20^{\circ} \mathrm{C}$. Blood (four fish per tank) was collected in heparinised vacutainers for plasma preparation. Intestinal contents (four fish per tank) from the pyloric intestine, mid-intestine and distal intestine were frozen in liquid $\mathrm{N}_{2}$ and then stored at $-80^{\circ} \mathrm{C}$. Pyloric caecal and liver tissues (six fish per tank) were sampled for histological evaluation, placed in $4 \%$ phosphate-buffered formaldehyde solution for $24 \mathrm{~h}$ and subsequently stored in $70 \%$ ethanol until further processing.

\section{Quantitative real-time PCR}

RNA purification and quality control, DNase treatment, complementary DNA synthesis, primer optimisation and quantitative PCR assays were carried out as described in detail elsewhere ${ }^{(35)}$. Quantitative PCR primers were obtained from the literature or designed using Primer3 (http://frodo. wi.mit.edu/primer3). The details of the primers are given in Table 2. Elongation factor $1 \alpha$ (ef1a), $\beta$-actin ( $a c t b)$, RNA polymerase II (rnapolII), hypoxanthine phosphoribosyltransferase 1 (bprt1), ribosomal protein S20 (rps20) and glyceraldehyde3-phosphate dehydrogenase ( $g a p d h)$ were evaluated for use as reference genes by ranking the expression levels according to their stability, as described previously ${ }^{(35)}$. For pyloric caecal and liver samples, rps 20 was used as the normalisation factor. The mean normalised expression of the target genes was calculated from raw quantification cycle (Cq) values ${ }^{(36)}$. 
(A)

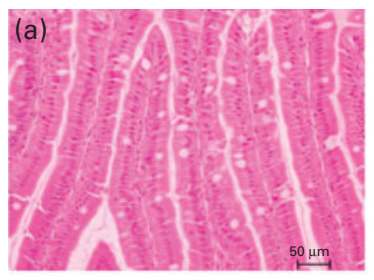

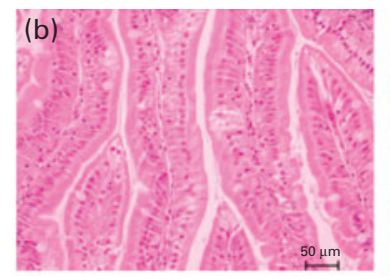
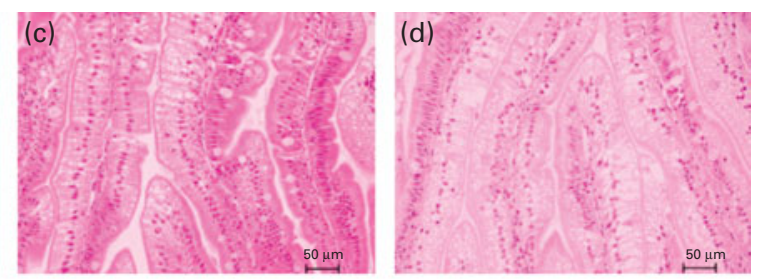

(B)
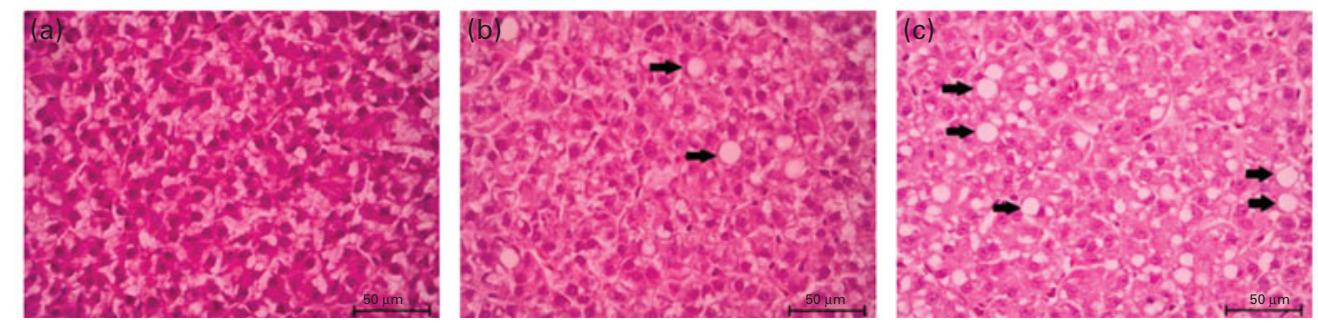

Fig. 1. Severity of steatosis of the pyloric (A) caeca and (B) liver of fish fed the experimental diets, representative for (a) absent (normal), (b) slight, (c) moderate and (d) marked. $\rightarrow$, Large vacuoles of TAG fat. (A colour version of this figure can be found online at http://www.journals.cambridge.org/bjn).

\section{Histology}

From each treatment group, twelve fish were used for histological evaluation. Pyloric caecal and liver samples were dehydrated in ethanol, equilibrated in xylene, embedded in paraffin and sectioned $(5 \mu \mathrm{m})$ according to standard histological techniques. Tissues were stained with haematoxylin and eosin. Blinded histological examination was carried out using a light microscope by paying particular attention to (presumed) lipid accumulation (steatosis) within enterocytes and hepatocytes. Steatosis was assessed using a categorical scoring system with grades of absent, slight, moderate and marked (Fig. 1).

\section{Cholesterol and bile salt analyses}

Plasma cholesterol and bile salt concentrations, as well as bile salt concentrations in the intestinal contents, were determined as described previously ${ }^{(12)}$. All analyses were carried out on Advia ${ }^{\circledR} 1800$ (Siemens Healthcare Diagnostics) at the Central Laboratory of the Norwegian School of Veterinary Science, Oslo, Norway.

\section{Statistical analyses}

Statistical analyses were carried out using JMP 10 (SAS Institute, Inc.). PM inclusion and SA inclusion were evaluated as class variables in a two-way ANOVA with interaction. For the histological evaluation of intestinal and liver samples, results were compared using a $\chi^{2}$ test. The level of significance was set at $P<0.05$.

\section{Results}

\section{Growth performance}

Growth performance was significantly affected by PM inclusion, but not by SA inclusion or the interaction between them (Fig. 2(A); Table 3). Feeding the PM-based diets resulted in significantly decreased final weight and specific growth rate (SGR) compared with feeding the FM diets by 24.8 and $20.7 \%$, respectively.

\section{Histology}

Lipid droplet accumulation in pyloric caecal enterocytes was significantly affected by PM inclusion (Table 4). Feeding the PM diets resulted in increased lipid droplet accumulation in enterocytes compared with feeding the FM diets. Similarly, the frequency of hepatic steatosis was significantly affected by PM inclusion (Table 4). Whereas none of the sampled fish fed the FM diets exhibited steatosis in the liver, several fish fed the PM diets exhibited slight-to-moderate hepatic steatosis. No significant interaction between PM inclusion and SA inclusion was observed.

\section{Cholesterol and bile salt levels}

Blood plasma cholesterol levels were significantly affected by both PM inclusion and SA inclusion (Fig. 2(B); Table 3). PM and/or SA supplementation significantly decreased blood plasma cholesterol levels. Moreover, a significant interaction between PM inclusion and SA inclusion was observed for this variable. The magnitude of the hypocholesterolaemic effects of SA on fish fed the PM-based diets was not as large as that of the effects on fish fed the FM diets. Plasma bile salt levels of fish were significantly decreased by SA inclusion. No effect of PM inclusion and no interaction between the saponin and dietary treatments were observed (Fig. 2(B); Table 3).

Digesta bile salt levels in the intestinal sections were significantly reduced by SA inclusion but not by PM inclusion (Fig. 2(C); Table 3).

\section{Gene expression profiling}

As shown in Fig. 3 and Table 3, PM inclusion had significant effects on pyloric caecal expression of key genes involved in 

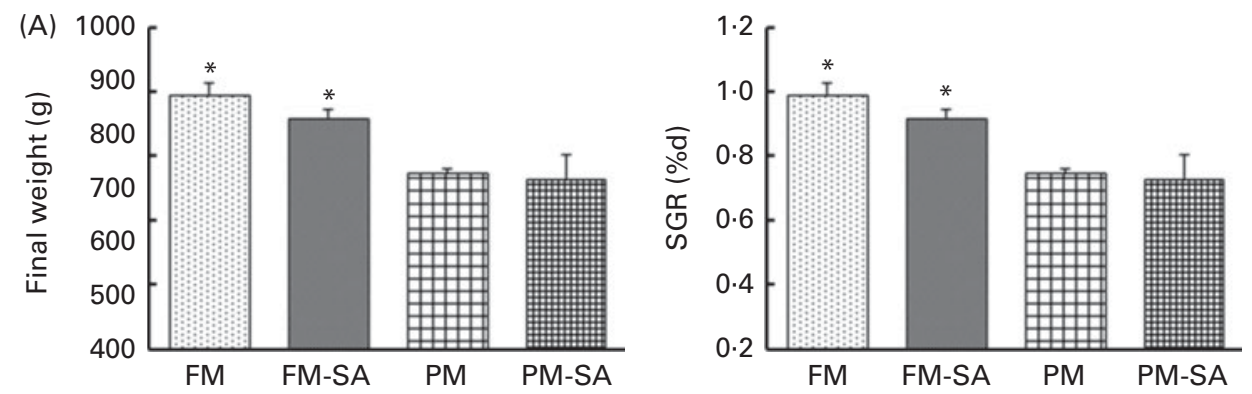

(B)
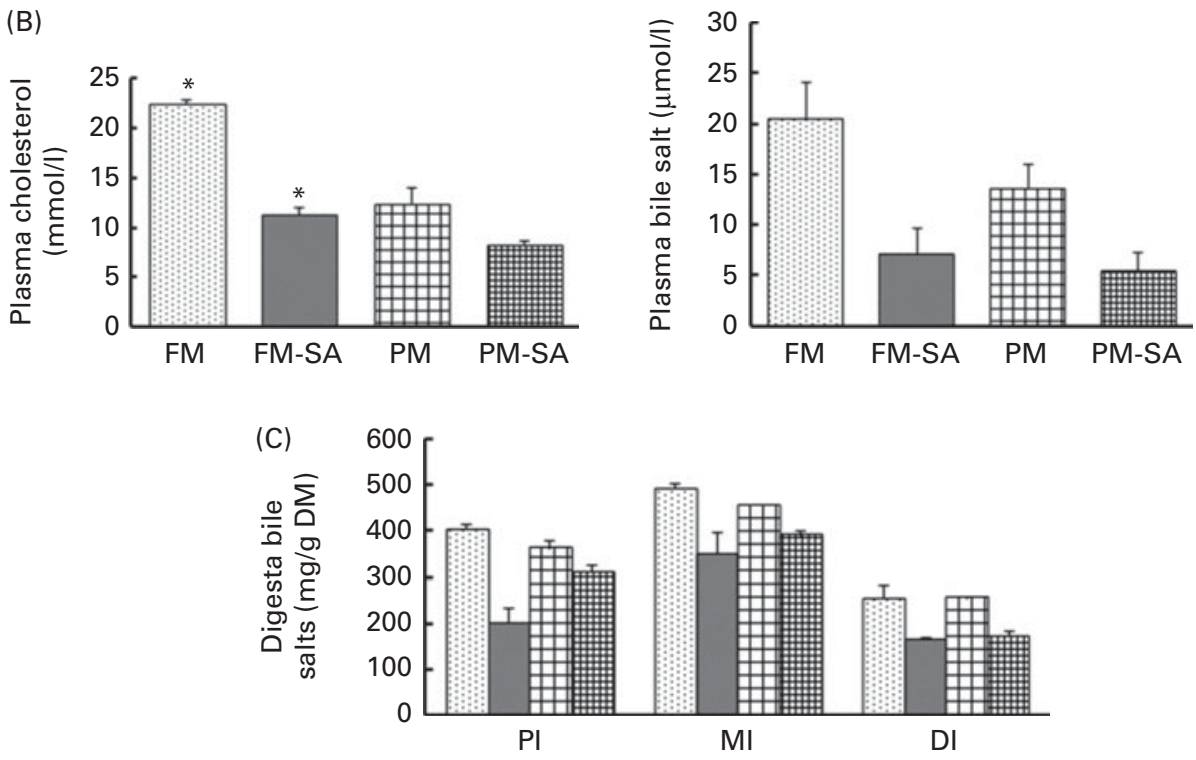

Fig. 2. Growth performance (A), concentrations of blood plasma cholesterol and bile salts (B) and concentrations of bile salts in digesta (C) of fish fed the exper-

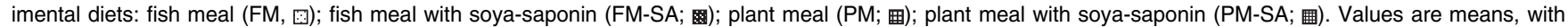
standard errors represented by vertical bars. * Mean values were significantly different from those for plant meal inclusion $(P<0.05$; two-way ANOVA). For plasma cholesterol, plasma bile salts and digesta bile salts, there was a significant effect for soya-saponin inclusion $(P<0.05$; two-way ANOVA). For plasma cholesterol, there was a significant interaction between plant meal and soya-saponin inclusion $(P<0.05$; two-way ANOVA). SGR, specific growth rate; $\mathrm{PI}$, pyloric intestine; MI, mid-intestine; DI, distal intestine.

lipid metabolism. Generally, PM inclusion induced the up-regulation of the expression of genes involved in LP assembly ( $a p o B, a p o A I, a p o A I V, m t p, a c a t, c h k$ and $p c y t 1 a)$ and FA transport ( $c d 36$, fatp and fabp2a1). SA inclusion upregulated the expression of genes encoding FA transporters (cd36, fatp and fabp2b) as well as the associated transcription factor ppar $\gamma$. Neither PM inclusion nor SA inclusion changed the expression of mgat $2 a$.

In the liver (Fig. 4; Table 3), similar to the results observed in the pyloric caeca, PM inclusion resulted in the up-regulation of the expression of genes involved in LP synthesis ( $a p o B$, apoAI and $m t p$ ) and fatty acid transport ( fatp). PM inclusion had significant effects on the expression of genes involved in cholesterol metabolism. PM inclusion resulted in the up-regulation of the expression of 3-hydroxy-3-methylglutaryl-CoA reductase ( $b m g c r$ ) as well as the associated transcription factors (sterol regulatory element-binding protein $2(\operatorname{srebp} 2)$ and ppar $\gamma$ ). SA inclusion had significant effects on the expression of genes involved in bile acid metabolism. Feeding SA-supplemented diets resulted in 11.5- and 8.3-fold down-regulation of the expression of cytochrome P450 7A1 (cyp7a1) compared with feeding the FM and PM diets, respectively. In parallel, SA supplementation resulted in reduced expression levels of liver $\mathrm{X}$ receptor $(l x r)$, bile acid transporter (ATP-binding cassette B11 (abcb11)) and cholesterol transporter (ATP-binding cassette G5 $(a b c g 5))$.

\section{Discussion}

\section{Effects of plant meal inclusion}

In the present study, dietary inclusion of PM reduced growth performance, induced lipid droplet accumulation in the pyloric caeca and liver, and decreased plasma cholesterol levels in Atlantic salmon. The reduction of growth performance by PM inclusion is in accordance with several previous studies in Atlantic salmon $^{(2,6,37)}$.

The present study indicates that the capacity for intestinal LP assembly was up-regulated in the PM diet-fed fish, probably as a result of excessive lipid droplet accumulation. Interestingly, the expression of $m g a t 2 a$, which is responsible for TAG re-esterification, remained unaffected by $\mathrm{PM}$ inclusion. In accordance with this observation, a number of studies have 
Table 3. Two-way ANOVA of the data for growth, cholesterol and bile salt levels, and gene expression of fish fed the experimental diets

\begin{tabular}{|c|c|c|c|}
\hline \multirow[b]{2}{*}{ Parameters } & \multicolumn{3}{|c|}{$P$} \\
\hline & PM & SA & $\mathrm{PM} \times \mathrm{SA}$ \\
\hline Final weight $(\mathrm{g})$ & 0.004 & 0.279 & 0.378 \\
\hline Specific growth rate $(\% / d)$ & 0.007 & 0.353 & 0.547 \\
\hline Plasma cholesterol ( $\mathrm{mmol} / \mathrm{l})$ & 0.002 & 0.001 & 0.018 \\
\hline Plasma bile salt $(\mu \mathrm{mol} / \mathrm{l})$ & $0 \cdot 172$ & 0.014 & 0.375 \\
\hline \multicolumn{4}{|l|}{ Digesta bile salt (mg/g DM) } \\
\hline Pyloric intestine & 0.164 & 0.003 & 0.020 \\
\hline Mid-intestine & 0.941 & 0.011 & 0.169 \\
\hline Distal intestine & 0.760 & 0.007 & $0 \cdot 880$ \\
\hline \multicolumn{4}{|c|}{ Gene expression in the pyloric caeca } \\
\hline mgat2a & 0.710 & 0.176 & 0.829 \\
\hline$a p o B$ & 0.025 & 0.730 & 0.955 \\
\hline apoAl & $<0.001$ & 0.843 & 0.052 \\
\hline apoAIV & $<0.001$ & 0.824 & 0.318 \\
\hline$m t p$ & 0.001 & 0.214 & 0.686 \\
\hline acat & 0.014 & 0.624 & 0.885 \\
\hline chk & $<0.001$ & 0.708 & 0.887 \\
\hline pcyt1a & $<0.001$ & 0.239 & 0.892 \\
\hline$c d 36$ & 0.001 & 0.002 & 0.389 \\
\hline fatp & 0.002 & 0.022 & 0.269 \\
\hline fabp2a1 & 0.026 & 0.272 & 0.631 \\
\hline$f a b p 2 b$ & 0.297 & $<0.001$ & 0.188 \\
\hline ppara & 0.243 & 0.160 & 0.740 \\
\hline ppary & 0.476 & 0.003 & 0.298 \\
\hline \multicolumn{4}{|l|}{ Gene expression in the liver } \\
\hline hmgcr & 0.005 & 0.412 & 0.940 \\
\hline srebp2 & 0.008 & 0.104 & 0.675 \\
\hline сур7а1 & 0.160 & $<0.001$ & 0.201 \\
\hline$a b c g 5$ & 0.556 & 0.006 & 0.478 \\
\hline$a b c b 11$ & 0.149 & 0.035 & 0.246 \\
\hline IXr & 0.104 & $<0.001$ & $0 \cdot 127$ \\
\hline$f x r$ & 0.088 & 0.625 & 0.182 \\
\hline ppar $\alpha$ & 0.308 & 0.189 & 0.458 \\
\hline ppary & $<0.001$ & 0.489 & 0.853 \\
\hline$a p o B$ & 0.038 & 0.437 & 0.262 \\
\hline apoAl & 0.001 & 0.201 & 0.682 \\
\hline$m t p$ & 0.007 & 0.218 & 0.875 \\
\hline acat & 0.852 & 0.113 & 0.459 \\
\hline fatp & 0.001 & 0.591 & 0.475 \\
\hline$c d 36$ & 0.247 & 0.277 & 0.967 \\
\hline
\end{tabular}

PM, plant meal; SA, soya-saponin; $\mathrm{PM} \times \mathrm{SA}$, interaction between plant meal and soya-saponins; mgat2a, monoacylglycerol acyltransferase 2-A; mtp, microsomal TAG transfer protein; acat, acyl-CoA cholesterol acyltransferase; chk, choline kinase; pcyt1a, choline-phosphate cytidylyltransferase 1A; cd36, cluster of differentiation 36; fatp, fatty acid transport protein; fabp2a1/fabp2b, fatty acid-binding protein 2 isoforms; ppara/ppary, PPAR isoforms; $h m g c r$, 3-hydroxy-3-methylglutaryl-CoA reductase; srebp2, sterol regulatory element-binding protein 2; cyp7a1, cytochrome P450 7A1; abcg5, ATP-binding cassette G5; abcb11, ATP-binding cassette $\mathrm{B} 11$; IXr, liver $\mathrm{X}$ receptor; $f x r$, farnesoid $\mathrm{X}$ receptor.

demonstrated that the accumulation of large lipid droplets (mainly consisting of TAG) in the intestine of fish is not due to the increased TAG re-esterification but rather due to lipid export rate reduction ${ }^{(38-42)}$. Therefore, the excessive lipid droplet accumulation observed in the present study, most probably, was a result of reduced lipid export from the intestinal mucosa to the circulatory system. The reason for this is not clear; however, deficient amounts of one or more of the major constituents of the polar LP surface, such as phosphatidylcholine (PC), apo and cholesterol, are probably responsible for this. In support of this, it has been shown that dietary supplementation with PC prevents intestinal steatosis in common carp larvae ${ }^{(38)}$.
In mammalian systems, molecular regulation of lipid absorption and transport from the intestine has been studied extensively ${ }^{(15,16,43,44)}$. The present study reveals novel information on the regulation of lipid absorption and transport in a piscine model, which is assumed to be generally similar to that in mammals ${ }^{(18,45,46)}$. A summary of the proposed regulation is shown in Fig. 5. Dietary lipids are exported from the intestine in the form of large, neutral lipid-rich LP. LP production in the enterocytes involves a series of biosynthetic processes that results in the formation of a large hydrophobic core surrounded by a thin coat of phospholipids (mainly PC), cholesterol and apo ${ }^{(43)}$. Clearly, phospholipids, cholesterol and apo are required for LP assembly. The positive effects of intestinal PC on LP formation have been demonstrated in mammals ${ }^{(47-49)}$. In fish, the ability of the enterocytes to export lipids may be limited by the absence of dietary $\mathrm{PC}^{(41,42)}$. As in mammals, de novo $\mathrm{PC}$ synthesis in fish occurs primarily via the cytidine diphosphate (CDP)-choline pathway with choline kinase producing phosphocholine recognised as the committing enzyme, followed by phosphocholine cytidylyltransferase producing CDP-choline, recognised as the ratelimiting and rate-regulatory enzyme ${ }^{(45)}$. In the present study, the expression of both $c h k$ and pycta1 was up-regulated in the PM diet-fed fish, indicating that the capacity for PC synthesis from choline was increased. PM inclusion also induced the up-regulation of the expression of genes encoding the $a p o B, a p o A I$ and $a p o A I V$, and an increased capacity for cholesterol esterification was indicated by the increased acat levels. In mammals, the increased mRNA expression of $m t p$ in the intestine has been considered to be a response to excessive lipid droplet accumulation ${ }^{(16)}$. The present study is in line with these studies, showing an up-regulation of the expression of $m t p$ in the pyloric caeca when steatosis was observed. In parallel to the overall transcriptional induction of LP synthesis, the expression of genes involved in FA transport was also induced, showing an up-regulation of the FA transporters $c d 36$ and fatp, as well as fabp2a1, which is responsible for FA transport from the cytoplasm to the endoplasmic reticu$\operatorname{lum}^{(48)}$. In FA transporter knockout animals, lipids tend to accumulate in the proximal small intestine primarily because of the decreased transport of FA targeted for transport to the circulatory system through their use in the assembly of $\mathrm{LP}^{(50)}$. However, it is likely that an efficient FA uptake from the intestinal lumen requires both spontaneous diffusion and protein-mediated transfer, and the relative importance of these two mechanisms is probably highly dependent on the microenvironment and tissue phenotype ${ }^{(44)}$. Altogether the present results suggest that PM inclusion up-regulated the capacity for LP synthesis and FA transport. The correlation between induced gene expression and increased lipid droplet accumulation suggests an induction of regulatory mechanisms to compensate for the reduced lipid export rate.

In line with our observations in the pyloric caeca, PM treatment resulted in hepatic fatty change and increased levels of genes ( $a p o B, a p o A I$ and $m t p)$ encoding key proteins involved in LP synthesis (mainly VLDL). These results suggest that similar regulatory mechanisms may exist in both the intestine and liver of fish fed the PM diets to compensate for the reduced 
Table 4. Severity of steatosis of the pyloric caeca and liver of fish fed the experimental diets*

\begin{tabular}{|c|c|c|c|c|c|c|c|}
\hline & \multirow[b]{2}{*}{ FM } & \multirow[b]{2}{*}{ FM-SA } & \multirow[b]{2}{*}{ PM } & \multirow[b]{2}{*}{ PM-SA } & \multicolumn{3}{|c|}{ Two-factor $\chi^{2}$ test $\dagger$} \\
\hline & & & & & PM & SA & $\mathrm{PM} \times \mathrm{SA}$ \\
\hline Intestinal steatosis & & & & & & 1.000 & 1.000 \\
\hline Absent (normal) & 10 & 9 & 0 & 0 & $<0.001$ & & \\
\hline Slight & 2 & 3 & 1 & 2 & & & \\
\hline Moderate & 0 & 0 & 8 & 7 & & & \\
\hline Marked & 0 & 0 & 3 & 3 & & & \\
\hline Hepatic steatosis & & & & & & 1.000 & 1.000 \\
\hline Absent (normal) & 12 & 12 & 8 & 4 & $<0.001$ & & \\
\hline Slight & 0 & 0 & 4 & 6 & & & \\
\hline Moderate & 0 & 0 & 0 & 2 & & & \\
\hline
\end{tabular}

lipid export rate. However, the increased lipid droplet accumulation in the liver of fish fed the PM may also result from an increase in lipolysis from adipose tissue ${ }^{(51-53)}$.

Gene expression profiling also indicated that the capacity for cholesterol synthesis was up-regulated in the PM diet-fed fish. This is in accordance with several previous studies ${ }^{(13,33,54-56)}$ and could reflect a general need for de novo cholesterol synthesis in PM-fed fish, probably as a direct result of reduced cholesterol body pools. The proposed regulation of hepatic cholesterol and bile acid synthesis is shown in Fig. 5. In mammals, the committed step in hepatic cholesterol biosynthesis is the synthesis of mevalonate by Hmgcr, and hmgcr mRNA transcription is controlled by Srebp ${ }^{(57,58)}$. At low sterol levels, Srebp are cleaved and translocated to the nucleus and these up-regulate the expression of genes involved in sterol metabolism ${ }^{(58)}$. The involvement of Srebp2 in the up-regulation of
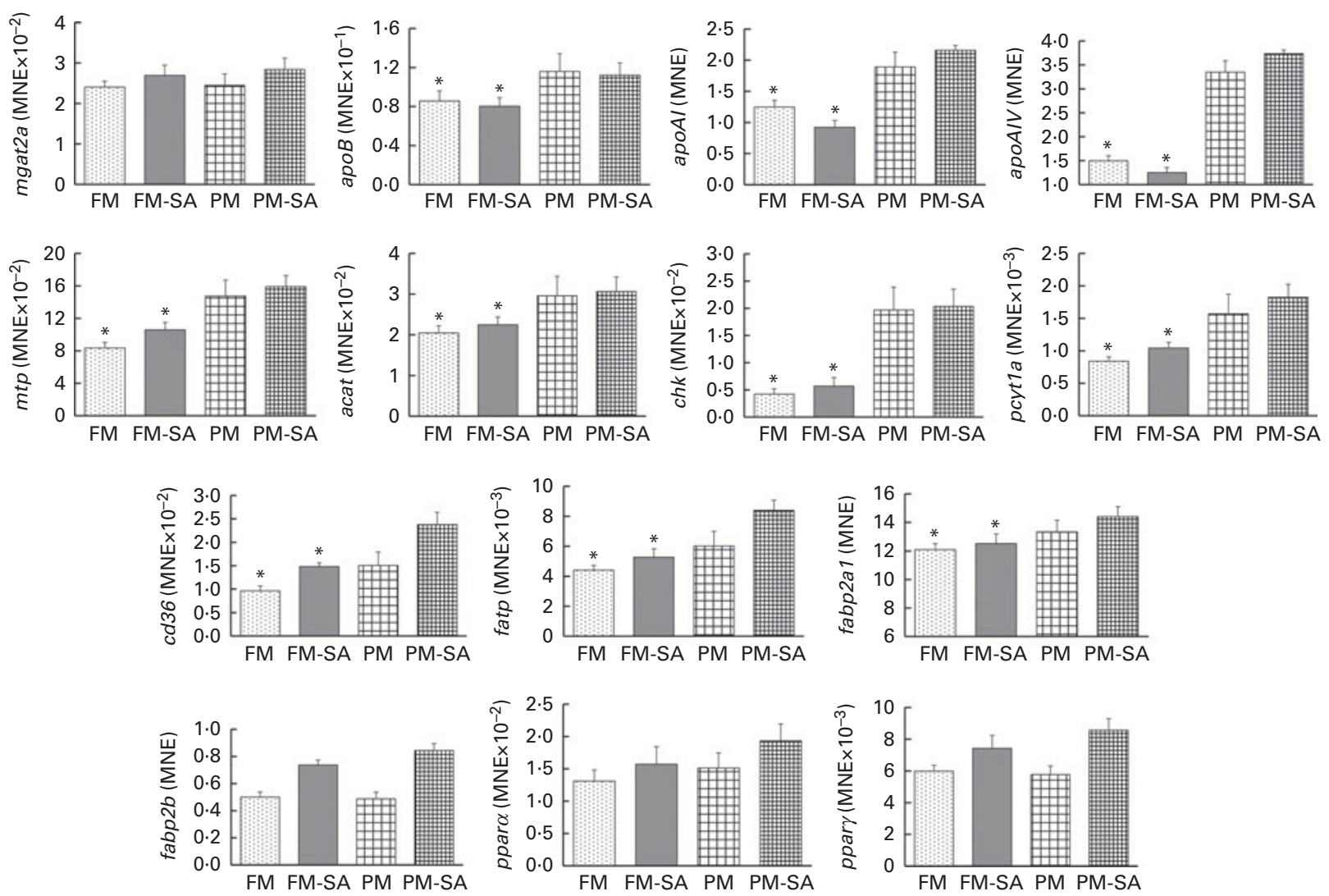

Fig. 3. Pyloric caecal gene expression of monoacylglycerol acyltransferase 2-A (mgat2a), apoB, apoAl, apoAIV, microsomal TAG transfer protein ( $m$ tp), acyl-CoA cholesterol acyltransferase (acat), choline kinase (chk), choline-phosphate cytidylyltransferase $1 \mathrm{~A}$ ( $p c y t 1 a)$, cluster of differentiation 36 (cd36), fatty acid transport protein (fatp), fatty acid-binding protein 2 isoforms ( fabp2a1/fabp2b) and PPAR isoforms (ppar $/$ ppar $\gamma$ ). Values are means, with standard errors represented by vertical bars. ${ }^{*}$ Mean values were significantly different from those for plant meal inclusion $(P<0.05$; two-way ANOVA). For $c d 36$, fatp, fabp2b and $p p a r \gamma$, there was a significant effect for soya-saponin inclusion ( $P<0.05$; two-way ANOVA). FM, Fish meal ( $\square$ ); FM-SA, fish meal with soya-saponin (圆); PM, plant meal (田); PM-SA, plant meal with soya-saponin (㬷); MNE, mean normalised expression. 

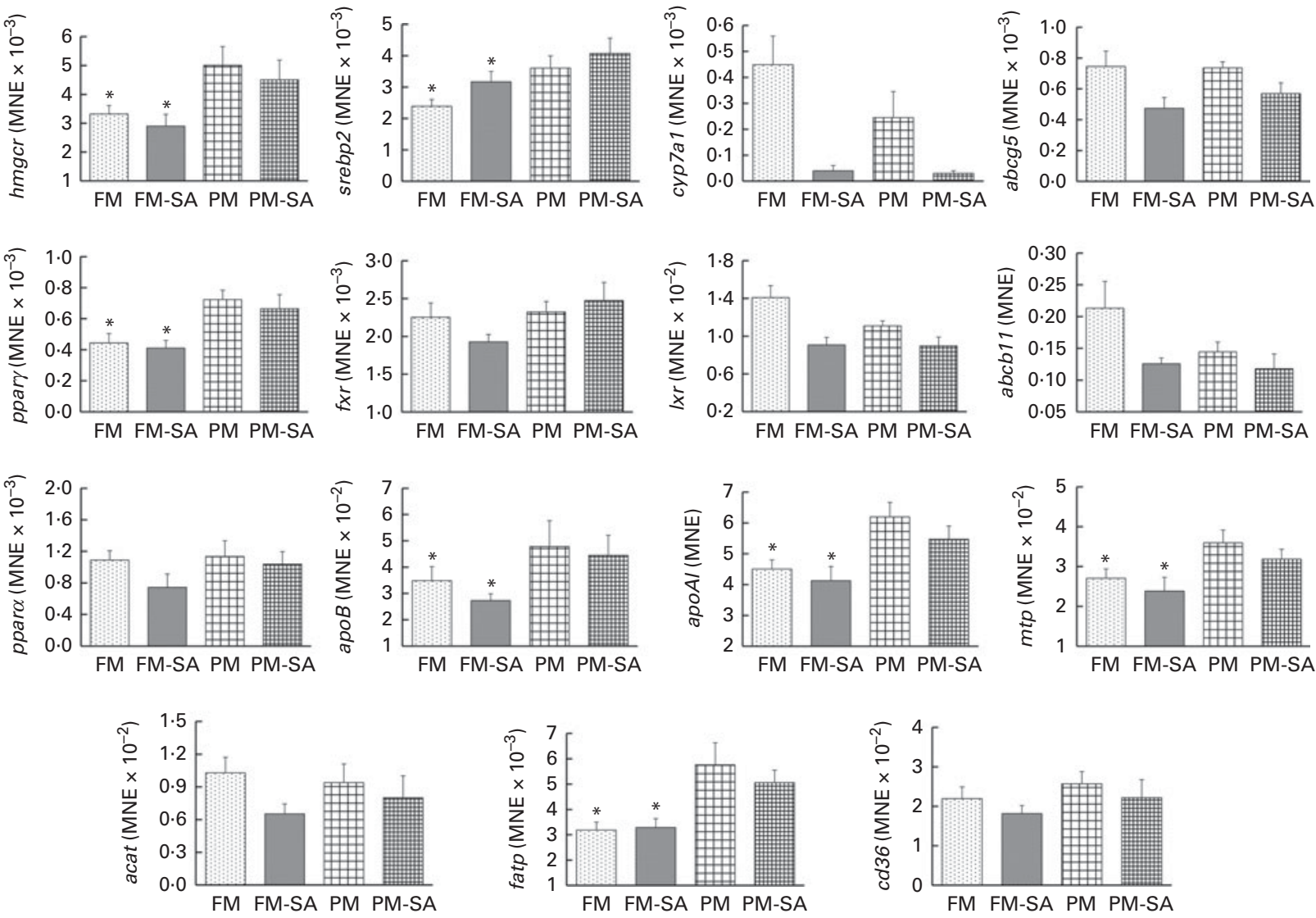

Fig. 4. Hepatic gene expression of 3-hydroxy-3-methylglutaryl-CoA reductase ( $h m g c r)$, sterol regulatory element-binding protein 2 (srebp2), cytochrome $P 4507 A 1$ (cyp7a1), ATP-binding cassette G5 and B11 (abcg5 and abcb11), liver X receptor (Ixr), farnesoid X receptor ( fxr), PPAR isoforms ( ppara/ppary), apoB, apoAI, microsomal TAG transfer protein ( $\mathrm{mtp}$ ), acyl-CoA cholesterol acyltransferase (acat), fatty acid transport protein ( fatp) and cluster of differentiation 36 (cd36). Values are means, with standard errors represented by vertical bars. ${ }^{*}$ Mean values were significantly different from those for plant meal inclusion $(P<0.05$; twoway ANOVA). For cyp7a1, abcg5, IXr and abcb11, there was a significant effect for soya-saponin inclusion $(P<0.05$; two-way ANOVA). FM, fish meal ( $\square)$; FM-SA, fish meal with soya-saponin (圆); PM, plant meal (田); PM-SA, plant meal with soya-saponin (眐); MNE, mean normalised expression.

cholesterol biosynthetic pathways has been shown in salmon fed plant products ${ }^{(33,54,57,59)}$. The present study is in line with these previous studies, showing increased mRNA levels of srebp2, as well as $h m g c r$, in fish fed the PM diets.

In addition to Srebp, Ppar are also important regulators of lipid and sterol metabolism and may interact and crosstalk with Srebp, Lxr and $\mathrm{Fxr}^{(60)}$. In an earlier study also conducted in salmon, ppary showed a stronger response to the diet supplemented with PM when compared with $\operatorname{ppar\alpha }^{(33)}$. The present study is in line with this report, as the hepatic expression of $p p a r \alpha$ remained unaffected by PM inclusion, whereas that of ppar $\gamma$ was up-regulated. The observed induction of the expression of ppar $\gamma$ could be a result of alterations in hepatic fat homeostasis, as some studies have demonstrated an enhanced expression of ppary in animal models of steatotic liver $^{(61-63)}$. Recent mammalian studies have also shown that Ppary regulates the expression of many genes involved in cholesterol transport and metabolism ${ }^{(64-67)}$.

\section{Effects of soya-saponin}

In the present study, SA inclusion significantly decreased plasma cholesterol levels. A number of studies have shown that saponin from different sources lowers plasma cholesterol levels in various animals (reviewed in Francis et al. ${ }^{(21)}$ ). These reports suggest that dietary saponins may be, at least partly, responsible for the hypocholesterolaemic effects of dietary PM in fish studies $^{(33,68)}$. Moreover, the present results showed a reduction in bile salt concentrations after SA exposure both in the intestinal lumen and in blood plasma. Many factors may possibly play a role in causing the decreased body pools of cholesterol and bile salt observed with dietary SA inclusion. For example, most saponins can form complexes with cholesterol and bile salts, thereby increasing their faecal excretion ${ }^{(69,70)}$. Additionally, SA has been shown to be an important factor responsible for the enteritis induced by dietary soyabean meal ${ }^{(22,23,71,72)}$. The saponin-induced intestinal inflammation seems to impair enterocyte maturation and may, therefore, limit bile salt reabsorption from the gut. Furthermore, the results of the present study indicated that the capacity for hepatic biosynthesis and secretion of bile salts was down-regulated by saponin exposure, which may aggravate the depletion of bile salts.

The classical pathway of primary bile acid synthesis mediated by the rate-limiting enzyme Cyp7a1 is thought to be the major contributor to bile salt synthesis in humans ${ }^{(60)}$. The basal expression of cyp $7 a 1$ is primarily controlled by one or more specific transcription factors, wherein positive and negative regulation is mediated by $\mathrm{Lxr}$ and $\mathrm{Fxr}$, respectively ${ }^{(73)}$. In the 

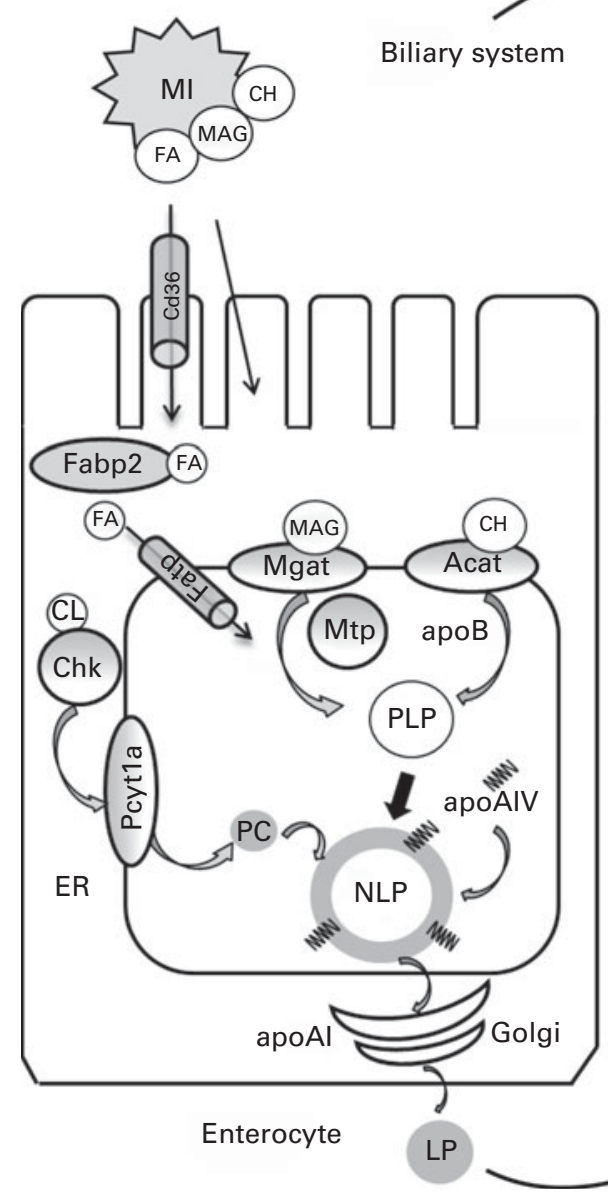

Fig. 5. Proposed molecular regulation of lipoprotein (LP) assembly, and cholesterol $(\mathrm{CH})$ and bile acid (BA) metabolism based on data from the present study and previous studies in fish and mammalian species. In the intestinal lumen, products of lipid hydrolysis are solubilised in micelles (MI) and presented to the apical membrane of enterocytes. Fatty acids (FA) are transported from the intestinal lumen into the enterocytes by protein transporters including Cd36 (cluster of differentiation 36) and fatty acid transport protein (Fatp) or by protein-independent diffusion. Within the cytoplasm, FA are shuttled by fatty acid-binding protein 2 (Fabp2). Acyl-CoA cholesterol acyltransferase (Acat) and monoacylglycerolacyltransferase (Mgat) are located in the endoplasmic reticulum (ER) membrane, where they facilitate the esterification of $\mathrm{CH}$ and monoacylglycerols (MAG), respectively. These esterified products are assembled into proximal lipoproteins (PLP) with apoB in a microsomal TAG transfer protein (Mtp)-dependent manner. The PLP is merged with apoAIV to form a nascent lipoprotein (NLP) by core expansion. Choline kinase (Chk) and choline-phosphate cytidylyltransferase (Pcyt1a) are the committed and rate-limiting enzymes in the synthesis of phosphatidylcholine (PC) from choline (CL). PC is used in the formation of the polar lipid coat of NLP. Within the Golgi lumen, apoAI is attached to NLP to form a mature LP. The LP is released from the enterocyte to enter the circulatory system. LP are transported to the liver, in fish supposedly via the portal veins, and recognised by LP receptor-related proteins (LRP). In hepatocytes, the intestinal LP are disassembled and new LP, i.e. VLDL, are formed. apoB and Mtp participate in the formation of VLDL. apoAl is also secreted by the liver. $\mathrm{CH}$ and primary $\mathrm{BA}$ are the major constituents of bile that are synthesised in the liver and released into the biliary duct via the specific membrane transporters ATP-binding cassette G5 and B11 (Abcg5 and Abcb11), respectively. Both CH and BA are stored in the gall bladder and released into the intestine upon ingestion of feed. In the hepatocytes, sterol regulatory element-binding protein 2 (Srebp2) up-regulates the expression of genes involved in $\mathrm{CH}$ synthesis (3-hydroxy-3-methyl-glutaryl-CoA reductase ( $\mathrm{hmgcr}$ )). Liver $\mathrm{X}$ receptor (Lxr) is activated by oxysterols, and it up-regulates the expression of genes involved in $\mathrm{CH}$ catabolism (cytochrome P4507A1 (cyp7a1)) and transport (abcg5). Farnesoid X receptor (Fxr) is activated by BA and controls intracellular BA levels by the regulation of Cyp7a1. PPAR isoforms (Ppar) are associated with the regulation of $\mathrm{CH}$ and BA metabolism, possibly by interaction with Srebp2. $\rightarrow$, Activation; - - inhibition; ----., possible interaction. 
present study, lxr mRNA levels were reduced after SA supplementation, but $f x r$ levels remained unaffected. As an important transcription factor in sterol metabolism in mammals and, mostly probably, fish ${ }^{(74)}, l x r$ transcripts have been cloned and characterised in salmonids ${ }^{(75)}$. The hepatic expression of $l x r$ has been shown to be higher in salmon fed fish oil than in those fed vegetable oil, which could be related to either dietary cholesterol/phytosterol contents or FA composition ${ }^{(75)}$. The results of the present study showed that saponins could be another factor inducing the down-regulation of the expression of $l x r$ in fish fed plant-derived alternatives. Consistent with the $l x r$ expression profile, the expression of cyp $7 a 1$ was markedly down-regulated by SA exposure. These results suggest that the capacity for hepatic bile acid biosynthesis was down-regulated in fish fed SA.

In the liver, the ATP-binding cassette Abcg5 (which forms a heterodimer with Abcg8) is regulated by Lxr activation and mediates cholesterol transport from the liver into the bile ${ }^{(76)}$. In the present study, the expression of both $\operatorname{abcg} 5$ and $\mathrm{lxr}$ was down-regulated by SA exposure. This result is in line with the previous observation that $a b c g 5$ and $l x r$ displayed similar gene expression profiles in the liver of salmon fed soyabean meal ${ }^{(33)}$. The reason for the down-regulation of the expression of $a b c g 5$ is not clear; however, it is probably a result of alterations in hepatic sterol metabolism induced by SA. Similarly, the hepatic expression of the bile salt transporter $a b c b 11$ was down-regulated by SA. Since the bile salt concentration is about 100- to 1000-fold higher in the bile than in the hepatocytes, canalicular bile salt transport represents the rate-limiting step in bile formation ${ }^{(60)}$, and Abcb11 is mainly responsible for bile salt transport across the canalicular membrane ${ }^{(76)}$. These results indicate that the capacity for bile salt transport from the liver to the biliary duct was decreased in fish fed SA.

In contrast to PM inclusion, SA inclusion did not affect lipid droplet accumulation or expression levels of genes involved in LP assembly. However, the expression of the FA transporters $c d 36$, fatp and fabp2b was up-regulated in the pyloric caeca, indicative of an enhanced capacity for intestinal FA absorption. SA inclusion decreased plasma and digesta bile salt levels and hepatic capacity for bile salt synthesis and transport. Given the key role of bile salts in fat emulsification and micelle formation, it is likely that the decreased body pools of bile salts affected intestinal lipid absorption. Thus, the enhanced capacity for FA transport could be a response to the decreased body pool of bile salts in fish fed saponins.

\section{Interaction}

Studies on interactions between different ingredients would be useful to avoid ingredient combinations causing negative effects in fish when using PM. However, in the present study, the hypocholesterolaemic effects of SA in the PM group were not as obvious as those in the FM group. Hepatic gene expression profiles indicated that the capacity for cholesterol biosynthesis was up-regulated in fish by PM exposure. Hardly any information exists regarding the interactions between SA and ingredients in lupin meal, and the mechanism behind the weakened hypocholesterolaemic effects of SA supplementation in the PM diets is not clear. However, the present results indicated that SA supplementation alone could have hypocholesterolaemic effects on Atlantic salmon.

\section{Conclusion}

PM inclusion in salmon feed resulted in decreased growth performance, excessive lipid droplet accumulation in the pyloric caeca and liver and reduced plasma cholesterol levels. Gene expression profiling suggested that the capacity for LP assembly and cholesterol synthesis was up-regulated by PM inclusion, probably occurring as a result of impaired lipid transport and cholesterol metabolism. SA inclusion had hypocholesterolaemic effects on Atlantic salmon, accompanied by decreased bile salt levels. Gene expression profiles indicated that the capacity for hepatic biosynthesis and secretion of bile salts was down-regulated by saponin exposure.

\section{Acknowledgements}

The authors thank the technicians and supporting researchers at the Nofima Marine research station at Sunndalsøra, Norway, for their skilful animal care and scientific follow-up and Ellen K. Hage, Elin C. Valen and Gunn C. Østby in their laboratory in Oslo for excellent technical assistance. They also thank China Scholarship Council (CSC) for providing financial assistance to M. G. as a visiting $\mathrm{PhD}$ student at the Norwegian School of Veterinary Science (NVH).

The present study was financially supported by the Research Council of Norway's Centre of Excellence Aquaculture Protein Centre (APC; grant no. 145949/120). APC had no role in the design and analysis of the study or in the writing of this article.

The authors' contributions were as follows: M. G. performed the gene expression and histopathology work and wrote the manuscript; T. M. K. guided the gene expression work and revised the manuscript; $M$. P. and $\AA$. K. designed and conducted the feeding trial and reviewed the manuscript. A. K. H. participated in the planning and conductance of the molecular work.

The authors declare that there are no conflicts of interest.

\section{References}

1. IFFO (International fishmeal and fish oil organization) (2011) What are fishmeal and fish oil? http://www.iffo.net/default. asp?contentID $=716$.

2. Van den Ingh TSGA, Krogdahl A, Olli JJ, et al. (1991) Effects of soybean-containing diets on the proximal and distal intestine in Atlantic Salmon (Salmo salar): a morphological study. Aquaculture 94, 297-305.

3. Baeverfjord G \& Krogdahl ^ (1996) Development and regression of soybean meal induced enteritis in Atlantic salmon, Salmo salar L., distal intestine: a comparison with the intestines of fasted fish. J Fish Dis 19, 375-387.

4. Refstie S, Korsøen ØJ, Storebakken T, et al. (2000) Differing nutritional responses to dietary defatted soybean meal in rainbow trout (Oncorbynchus mykiss) and Atlantic salmon (Salmo salar). Aquaculture 190, 49-63.

5. Van den Ingh TSGA, Olli JJ \& Krogdahl A (1996) Alcoholsoluble components in soybeans cause morphological 
changes in the distal intestine of Atlantic salmon. Salmo salar L. J Fish Dis 19, 47-53.

6. Olli JJ, Krogdahl Å, Ingh T, et al. (1994) Nutritive value of four soybean products in diets for Atlantic salmon. Acta Agr Scand Sect 44, 50-60.

7. Kaushik SJ, Cravedi JP, Lalles JP, et al. (1995) Partial or total replacement of fish meal by soybean protein on growth, protein utilization, potential estrogenic or antigenic effects, cholesterolemia and flesh quality in rainbow trout, Oncorbynchus mykiss. Aquaculture 133, 257-274.

8. Krogdahl A, Bakke-McKellep AM \& Baeverfjord G (2003) Effects of graded levels of standard soybean meal on intestinal structure, mucosal enzyme activities, and pancreatic response in Atlantic salmon (Salmo salar L.). Aquaculture Nutr 9, 361-371.

9. Romarheim OH, Skrede A, Gao Y, et al. (2006) Comparison of white flakes and toasted soybean meal partly replacing fish meal as protein source in extruded feed for rainbow trout (Oncorbynchus mykiss). Aquaculture 256, 354-364.

10. Yamamoto T, Suzuki N, Furuita H, et al. (2007) Supplemental effect of bile salts to soybean meal-based diet on growth and feed utilization of rainbow trout Oncorbynchus mykiss. Fish Sci 73, 123-131.

11. Romarheim OH, Skrede A, Penn M, et al. (2008) Lipid digestibility, bile drainage and development of morphological intestinal changes in rainbow trout (Oncorbynchus mykiss) fed diets containing defatted soybean meal. Aquaculture 274, 329-338.

12. Sørensen M, Penn M, El-Mowafi A, et al. (2011) Effect of stachyose, raffinose and soya-saponin supplementation on nutrient digestibility, digestive enzymes, gut morphology and growth performance in Atlantic salmon (Salmo salar, L). Aquaculture 314, 145-152.

13. Geay D, Ferraresso S, Zambonino-Infante JL, et al. (2011) Effects of the total replacement of fish-based diet with plant-based diet on the hepatic transcriptome of two European sea bass (Dicentrarchus labrax) half-sibfamilies showing different growth rate with the plant-based diet. BMC Genomics 12, 522-539.

14. Henderson RJ \& Tocher DR (1987) The lipid composition and biochemistry of freshwater fish. Progr Lipid Res 26, 281-347.

15. Mansbach GorelickF II CM (2007) Development and physiological regulation of intestinal lipid absorption. II. Dietary lipid absorption, complex lipid synthesis, and the intracellular packaging and secretion of chylomicrons. Am J Physiol 293, 645-650.

16. Black DD (2007) Development and physiological regulation of intestinal lipid absorption. I. Development of intestinal lipid absorption: cellular events in chylomicron assembly and secretion. Am J Physiol 293, G519-G524.

17. Sire MF, Lutton C \& Vernier JM (1981) New views on intestinal absorption of lipids in teleostean fishes: an ultrastructural and biochemical study in the rainbow trout. J Lipid Res $\mathbf{2 2}$, 81-94.

18. Tocher DR (2003) Metabolism and functions of lipids and fatty acids in teleost fish. Rev Fish Sci 11, 107-184.

19. Shi J, Arunasalam K, Yeung D, et al. (2004) Saponin from edible legumes: chemistry, processing, and health benefits. J Med Food 7, 67-78.

20. Krogdahl $\AA$, Penn M, Thorsen J, et al. (2010) Important antinutrients in plant feedstuffs for aquaculture: an update on recent findings regarding responses in salmonids. Aquacult Res 41, 333-344.
21. Francis G, Kerem Z, Makkar HP, et al. (2002) The biological action of saponin in animal systems: a review. Br J Nutr $\mathbf{8 8}$, 587-605.

22. Knudsen D, Uran P, Arnous A, et al. (2007) Saponin-containing subfractions of soybean molasses induce enteritis in the distal intestine of Atlantic salmon. J Agric Food Chem 55, 2261-2267.

23. Knudsen D, Jutfelt F, Sundh H, et al. (2008) Dietary soya saponin increase gut permeability and play a key role in the onset of soyabean-induced enteritis in Atlantic salmon (Salmo salar L.). Br J Nutr 100, 120.

24. Southon S, Johnson IT, Gee JM, et al. (1988) The effect of Gypsophylla saponin in the diet on mineral status and plasma cholesterol concentration in the rat. Br J Nutr 59, 49-55.

25. Harwood HJ Jr, Chandler CE, Pellarin LD, et al. (1993) Pharmacologic consequences of cholesterol absorption inhibition: alteration in cholesterol metabolism and reduction in plasma cholesterol concentration induced by the synthetic saponin b-tigogenin cellobioside (CP-88818; tiqueside). J Lipid Res 34, 377-395.

26. Potter SM, Jimenez-Flores R, Pollack J, et al. (1993) Protein saponin interaction and its influence on blood lipids. J Agric Food Chem 41, 1287-1291.

27. Matsuura M (2001) Saponin in garlic as modifiers of the risk of cardiovascular disease. J Nutr 131, 1000-1005.

28. Al-Habori M \& Raman A (1998) Antidiabetic and hypocholesterolaemic effects of fenugreek (Review). Phytother Res 12, 233-242.

29. Calvert GD \& Blight L (1981) A trial of the effects of soyabean flour and soya-bean saponin on plasma lipids, fecal bile acids and neutral sterols in hypercholesterolaemic men. Br J Nutr 45, 277-281.

30. Story JA, LePage SL, Petro MS, et al. (1984) Interactions of alfalfa plant and sprout saponin with cholesterol in vitro and in cholesterol-fed rats. Am J Clin Nutr 39, 917-929.

31. Sugano M, Goto S, Kimoto M, et al. (1990) Cholesterol lowering activity of various undigested fractions of soybean protein in rats. J Nutr 120, 977-985.

32. Jenkins KJ \& Atwal AS (1994) Effects of dietary saponin on fecal bile acids and neutral sterols, and availability of vitamins $\mathrm{A}$ and $\mathrm{E}$ in the chick. $J$ Nutr Biochem 5, 134-138.

33. Kortner TM, Gu JN, Krogdahl $\AA$, et al. (2013) Transcriptional regulation of cholesterol and bile acid metabolism after dietary soyabean meal treatment in Atlantic salmon (Salmo salar L.). Br J Nutr 109, 593-604.

34. Committee on the Nutrient Requirements of Fish and Shrimp \& National Research Council (2011) Minerals. Vitamins. In Nutrient Requirements of Fish and Shrimp, pp. 163-120. Washington, DC: National Academies Press.

35. Kortner TM, Valen EC, Kortner H, et al. (2011) Candidate reference genes for quantitative real-time PCR (qPCR) assays during development of a diet-related enteropathy in Atlantic salmon (Salmo salar L.) and the potential pitfalls of uncritical use of normalization software tools. Aquaculture 318, 355-363.

36. Muller PY, Janovjak H, Miserez AR, et al. (2002) Processing of gene expression data generated by quantitative real-time RT-PCR. Biotechniques 32, 1372-1374, 1378, 1379.

37. Olli JJ \& Krogdahl A (1995) Dehulled solvent-extracted soybean meal as a protein source in diets for Atlantic salmon Salmo salar L. Aquaculture Res 26, 167-174.

38. Fontagné S, Geurden I, Escaffre AM, et al. (1998) Histological changes induced by dietary phospholipids in intestine and liver of common carp (Cyprinus carpio L.) larvae. Aquaculture 161, 213-223. 
39. Fontagné S, Burtaire L, Corraze G, et al. (2000) Effects of dietary medium-chain triacylglycerols (tricaprylin and tricaproin) and phospholipid supply on survival, growth and lipid metabolism in common carp (Cyprinus carpio L.) larvae. Aquaculture 190, 289-303.

40. Olsen RE, Myklebust R, Kaino T, et al. (1999) Lipid digestibility and ultrastructural changes in the enterocytes of Arctic char (Salvelinus alpinus L.) fed linseed oil and soybean lecithin. Fish Physiol Biochem 21, 35-44.

41. Olsen R, Dragnes BT, Myklebust R, et al. (2003) Effect of soybean oil and soybean lecithin on intestinal lipid composition and lipid droplet accumulation of rainbow trout Oncorbynchus mykiss Walbaum. Fish Physiol Biochem 29, 181-192.

42. Daprà F, Geurden I \& Corraze G (2011) Physiological and molecular responses to dietary phospholipids vary between fry and early juvenile stages of rainbow trout (Oncorbynchus mykiss). Aquaculture 319, 377-384

43. Iqbal J \& Hussain MM (2009) Intestinal lipid absorption. Am J Physiol Endocrinol Metab 296, 1183-1194.

44. Niot I, Poirier H, Tran TT, et al. (2009) Intestinal absorption of long-chain fatty acids: evidence and uncertainties. Prog Lipid Res 48, 101-115.

45. Tocher DR, Bendiksen EA, Campbell PJ, et al. (2008) The role of phospholipids in nutrition and metabolism of teleost fish. Aquaculture 280, 21-34

46. Bakke AM, Glover C \& Krogdahl A (2011) Feeding, digestion and absorption of nutrients. In The Multifunctional Gut of Fish, vol. 30, pp. 57-110 [M Grosel, AP Farrel and CJ Brauner, editors] Amsterdam: Elsevier.

47. O'Doherty P, Kakis G \& Kuksis A (1973) Role of luminal lecithin in intestinal fat absorption. Lipids 8, 249-255.

48. Field FJ \& Mathur SN (1995) Intestinal lipoprotein synthesis and secretion. Prog Lipid Res 34, 185-198.

49. Wang H, Du J, Lu S, et al. (2001) Regulation of intestinal apolipoprotein A-I synthesis by dietary phosphatidylcholine in newborn swine. Lipids 36, 683-687.

50. Drover VA, Ajmal M, Nassir F, et al. (2005) CD36 deficiency impairs intestinal lipid secretion and clearance of chylomicrons from the blood. J Clin Invest 115, 1290-1297.

51. Albalat A, Gutierrez J \& Navarro I (2005) Regulation of lipolysis in isolated adipocytes of rainbow trout (Oncorbynchus mykiss): the role of insulin and glucagon. Comp Biochem Physiol 142, 347-354.

52. Saera-Vila A, Calduch-Giner JA, Gomez-Requeni $\mathrm{P}$, et al. (2005) Molecular characterization of gilthead sea bream (Sparus aurata) lipoprotein lipase. Transcriptional regulation by season and nutritional condition in skeletal muscle and fat storage tissues. Comp Biochem Physiol 142, 224-232.

53. Bouraoui L, Sánchez-Gurmaches J, Cruz-Garcia J, et al. (2011) Effect of dietary fish meal and fish oil replacement on lipogenic and lipoprotein lipase activities and plasma insulin in gilthead sea bream (Sparus aurata). Aquacult Nutr 17, 54-63.

54. Leaver MJ, Villeneuve LAN, Obach A, et al. (2008) Functional genomics reveals increases in cholesterol biosynthetic genes and highly unsaturated fatty acid biosynthesis after dietary substitution of fish oil with vegetable oils in Atlantic salmon (Salmo salar). BMC Genomics 9, 299

55. Vilhelmsson OT, Martin SAM, Medale F, et al. (2004) Dietary plant-protein substitution affects hepatic metabolism in rainbow trout (Oncorbynchus mykiss). Br J Nutr 92, 71-80.

56. Panserat S, Hortopan GA, Plagnes-Juan E, et al. (2009) Differential gene expression after total replacement of dietary fish meal and fish oil by plant products in rainbow trout (Oncorbynchus mykiss) liver. Aquaculture 294, 123-131.

57. Brown MS \& Goldstein JL (1997) The SREBP pathway: regulation of cholesterol metabolism by proteolysis of a membrane-bound transcription factor. Cell 89, 331-340.

58. Goldstein JL, DeBose-Boyd RA \& Brown MS (2006) Protein sensors for membrane sterols. Cell 124, 35-46.

59. Morais S, Taggart JB, Guy DR, et al. (2011) Hepatic transcriptome analysis of inter-family variability in flesh $n-3$ long-chain polyunsaturated fatty acid content in Atlantic salmon. BMC Genomics 13, 410

60. Li TG \& Chiang JYL (2009) Regulation of bile acid and cholesterol metabolism by PPARs. PPAR Res 2009, 501739.

61. Gavrilova O, Haluzik M, Matsusue K, et al. (2003) Liver peroxisome proliferator-activated receptor contributes to hepatic steatosis, triglyceride clearance, and regulation of body fat mass. J Biol Chem 278, 34268-34276.

62. Matsusue K, Haluzik M, Lambert G, et al. (2003) Liverspecific disruption of PPAR in leptin-deficient mice improves fatty liver but aggravates diabetic phenotypes. J Clin Invest 111, 737-747

63. Yu S, Matsusue K, Kashireddy P, et al. (2003) Adipocytespecific gene expression and adipogenic steatosis in the mouse liver due to peroxisome proliferator-activated receptor $\gamma 1$ (PPAR $\gamma 1$ ) overexpression. J Biol Chem 278, 498-505.

64. Baker AD, Malur A, Barna BP, et al. (2010) PPAR $\gamma$ regulates the expression of cholesterol metabolism genes in alveolar macrophages. Biochem Biophys Res Commun 393, 682-687.

65. Thomassen MJ, Barna BP, Malur A, et al. (2007) ABCG1 is deficient in alveolar macrophages of GM-CSF knock-out mice and patients with pulmonary alveolar proteinosis J Lipid Res 48, 2762-2768.

66. Zelcer N \& Tontonoz P (2006) Liver X receptors as integrators of metabolic and inflammatory signaling. J Clin Invest 116, 607-614.

67. Chawla A, Boisvert WA, Laffitte BA, et al. (2001) A PPAR gamma-LXR-ABCA1 pathway in macrophages is involved in cholesterol efflux and atherogenesis. Mol Cell 7, 161-171.

68. Yun BA, Mai KS, Zhang WB, et al. (2011) Effects of dietary cholesterol on growth performance, feed intake and cholesterol metabolism in juvenile turbot (Scophthalmus maximus L.) fed high plant protein diets. Aquaculture 319, 105-110

69. Oakenfull DG (1986) Aggregation of bile acids and saponin in aqueous solution. Aust J Chem 39, 1671-1683.

70. Oakenfull DG \& Sidhu GS (1990) Could saponin be a useful treatment for hypercholesterolemia? Eur J Clin Nutr $\mathbf{4 4}$ 79-88.

71. Kortner TM, Skugor S, Penn MH, et al. (2012) Dietary soyasaponin supplementation to pea protein concentrate reveals nutrigenomic interactions underlying enteropathy in Atlantic salmon (Salmo salar L.). BMC Vet Res 8, 101.

72. Chikwati E, Venold FF, Penn MH, et al. (2012) Interaction of soyasaponins with plant ingredients in diets for Atlantic salmon, Salmo salar L. Br I Nutr 107, 1570-1590.

73. Gadaleta RM, van Mil SWC, Oldenburg B, et al. (2010) Bile acids and their nuclear receptor FXR: relevance for hepatobiliary and gastrointestinal disease. Biochim Biophys Acta Mol Cell Biol Lipids 1801, 683-692.

74. Archer A, Lauter G, Hauptmann G, et al. (2008) Transcriptional activity and developmental expression of liver $\mathrm{X}$ receptor (lxr) in zebrafish. Dev Dyn 237, 1090-1098.

75. Cruz-Garcia L, Minghetti M, Navarro I, et al. (2009) Molecular cloning, tissue expression and regulation of liver $\mathrm{X}$ receptor (LXR) transcription factors of Atlantic salmon (Salmo salar) and rainbow trout (Oncorbynchus mykiss). Comp Biochem Physiol B 153, 81-88. 
76. Chawla A, Repa JJ, Evans RM, et al. (2001) Nuclear receptors and lipid physiology: opening the X-files. Science 294 , 1866-1870.

77. Torstensen BE, Espe M, Stubhaug I, et al. (2011) Dietary plant proteins and vegetable oil blends increase adiposity and plasma lipids in Atlantic salmon (Salmo salar L.). Br J Nutr 106, 633-647.

78. Venold FF, Penn MH, Thorsen J, et al. (2013) Intestinal fatty acid binding protein (fabp2) in Atlantic salmon (Salmo salar): localization and alteration of expression during development of diet induced enteritis. Comp Biochem Physiol A 164, 229-240.

79. Minghetti M, Leaver MJ \& Tocher DR (2011) Transcriptional control mechanisms of genes of lipid and fatty acid metabolism in the Atlantic salmon (Salmo salar L.) established cell line, SHK-1. Biochim Biophys Acta 1811, 194-202.

80. Zaja R, Munić V, Klobucar RS, et al. (2008) Cloning and molecular characterization of apical efflux transporters (ABCB1, $\mathrm{ABCB} 11$ and $\mathrm{ABCC} 2$ ) in rainbow trout (Oncorbynchus mykiss) hepatocytes. Aquat Toxicol 90, 322-332. 